\title{
Inequality in Latin America: ECLAC's Perspective
}

\author{
Verónica Amarante and Antonio Prado
}

Equality has been at the center of ECLAC's analysis of the region since structuralist times. In those pioneering writings, the distribution of assets and the concentration of power in the hands of elites were crucial aspects to understand (the lack of) equality in the region. Following this tradition, the last three documents that the institution submitted for consideration by the Governments of Latin America and the Caribbean at its three last sessions have put equality back in the center of the regional agenda, expanding the conception of equality beyond distributive fairness - whose scope tends to be confined to the distribution of transferable, quantifiable resources - taking in other dimensions and considering equality in a "relational" context of socialization, autonomy, and recognition.

As put forth in Time for equality: closing gaps, opening trails (ECLAC 2010), the quest for equality is part of the drive to abolish privileges and establish equal rights for all individuals, regardless of origin, affiliations, or position in society. It calls not only for universal civil and political rights but also for advancing towards distributive justice in which everyone enjoys the benefits of progress. Time for equality argued that equality stands at the crossroads between economic growth, social inclusion, and recognition of diversity, advocating a kind of development that forges a positive link between greater equality and gains in productivity, capacities, and sustainable growth. The document postulated that social equality and the kind of economic dynamism that transform production patterns are not at odds with each other and that the challenge is to find synergies between the two. The growth strategy should include less structural heterogeneity and more productive development, and the pursuit of equality through the enhancement of human capacities and the mobilization of state energies. The basic idea is the need of building more cohesive societies around productive dynamics, constructing positive social and territorial synergies, and strengthening the protection of individuals through improvements in labor markets.

\footnotetext{
V. Amarante $(\varangle) \cdot$ A. Prado

Economic Commission for Latin America and the Caribbean (ECLAC), Santiago, Chile 
The economic content of this approach was further developed in Structural Change for Equality: An Integrated Vision of Development (ECLAC 2012), which understands structural change as the path leading to greater equality. In this vision, structural change means putting qualitative changes in the production structure at the centre of the growth dynamic. Improved global insertion and virtuous growth in domestic productivity and employment call for greater participation by knowledge-intensive sectors in overall production. This fosters the building of capacities, knowledge, and learning in coordination with production and investment across the economy. For the region, structural change must take place on two interconnected fronts: enhancing the share of more knowledge-intensive sectors in production and trade, and diversifying towards sectors where domestic and external demand is expanding rapidly, so that demand can be met with domestic supply and imports and exports can grow in a balanced manner without putting unsustainable pressure on the balance of payments. By centering growth on the creation of new sectors and the dissemination of technology throughout the system, structural change creates job opportunities in higher productivity sectors while pushing labor market participation rates up and unemployment and informality rates down. In the long run, this strategy would lead to poverty and inequality reduction. When the production structure is very polarized, purely redistributive fiscal and social mechanisms do not solve the problems of inequality and slow growth in the long run. Sooner than later, policies will have to target the generation of job and training opportunities in the framework of structural change. The adoption of industrial policies that encourage this transformation should be considered, along with social policies, as they are key dimensions of the equality horizon. For example, production linkages are part of structural change; they prevent concentration and disseminate gains throughout society. Conversely, social and redistributive policies should accompany industrial policy. For one, they improve distribution and reduce vulnerability in the short term, creating an intertemporal linkage that enables structural change-oriented policies to achieve their redistributive impacts, which are longer term. Moreover, social policy should protect the most disadvantaged sectors during the disruptive periods of structural change (when sector realignment can involve periods of adjustment with unemployment), as well as from the social impacts of external or other shocks.

The most recent session document, Compacts for equality (ECLAC 2014a), gets deeper into the concept of equality that ECLAC wants to promote, stating that it includes equality of means, opportunities, and capacities, but in the framework of a deeper understanding of equality as the equal dignity of citizens, in which individuals are simultaneously autonomous and vulnerable and should be acknowledged for both qualities mutually. In this framework, the document provides a detailed analysis of inequality in different dimensions in Latin America, arguing that equality gains in the region in the last decade are not seen in all dimensions but mainly confined to means, most notably income inequality. The document also points to warning signs relating to structural components that drive inequality, both productive and social. Although many improvements took place, the main warning signs refer to the absence of structural changes mainly in the 
production sectors, but also in some aspects of social sectors. The closing part of the document focuses on how strategic visions of a more egalitarian and sustainable development can be built into the rationale for collective accords between stakeholders.

Embracing a broader conception of equality which goes beyond means or resources does not imply at all that resource inequality is considered unimportant in ECLAC's view. Indeed, alongside its history, ECLAC has contributed substantially to the analysis and understanding of income inequality in the region, considering its determinants both in terms of structuralist theory and from the various perspectives developed within the institution itself. Given the scope of this volume, the following pages aim to reflect some of the most recent contributions from ECLAC in relation to the analysis of income inequality. But this is done within this wider scope, reinforcing different dimensions of inequality and considering the importance of labour market institutions. In the following sections, we first describe the recent evolution of income inequality in Latin America (Sect. 1) and then consider the role that the labour market, and specifically the minimum wage and the formalization process, has had in some countries in the region (Sect. 2). We then turn into gender inequalities, analysing female labour participation and its potential impacts on poverty and inequality (Sect. 3). Finally, we present some concluding remarks (Sect. 4).

\section{Recent Evolution of Income Inequality in Latin America}

Inequality in resource distribution, and specifically in income distribution, is one distinguishing feature of Latin America. Recent comparisons of Gini coefficients on household consumption per capita calculated for developing regions do confirm that the median Gini is higher in Latin America and the Caribbean, although the mean Gini is slightly lower than in sub-Saharan Africa (Alvaredo and Gasparini 2015). In any case, the levels of inequality are high for almost every country in the region, and undoubtedly inequality is a persistent characteristic of LAC.

In the last 15 years, income inequality has shown a significant decrease. This decline in inequality derives from higher income growth at lower income percentiles in the region. Figure 1 illustrates this evolution, based on pooled countryspecific household data for 18 countries. We consider two alternative exchange rates to convert national currencies into a common numeraire: purchasing power parity (PPP) exchange rates, and ECLAC poverty lines for each country. For both variables, income growth has been significantly higher among lower income households, consistently with the important reduction in income poverty that the region experimented in this period (see ECLAC 2014b). 


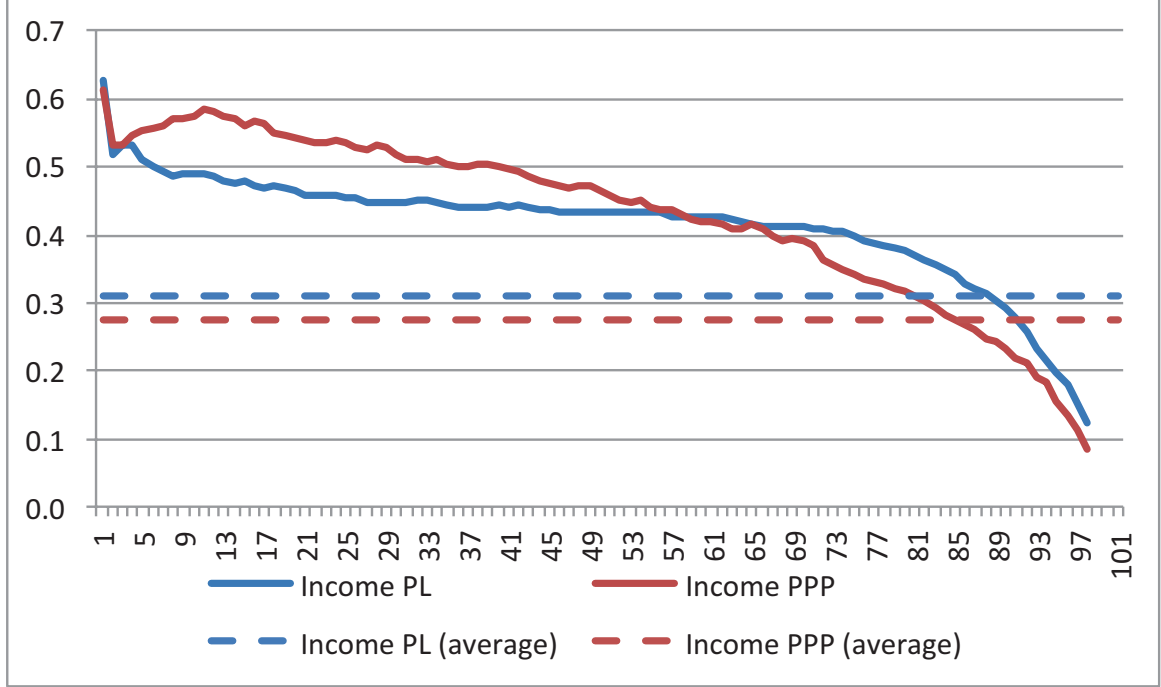

Fig. 1 Latin America: Growth incidence curve of household per capita income 2002-2012. Source: Economic Commission for Latin America and the Caribbean (ECLAC), on the basis of special tabulations of data from household surveys conducted in the respective countries, and World Development Indicators

If we turn into inequality by country, in all countries in the region, with the exception of Costa Rica, Dominican Republic, and Guatemala, household surveys report a decrease in the Gini coefficient of household per capita income between 2002 and 2013 (Table 1). The decreased trend is present when data for 2009 is considered, and continues for most countries for the latest available data. The magnitude of the decline has been differential by countries, with decreases above $5 \%$ in Argentina, Bolivia, and Venezuela. All other measures of income inequality show a similar pattern of statistically significant reduction in inequality (see ECLAC 2013, 2014b) among others.

Abundant research has tried to understand the distributive turnaround in Latin America. A microeconometric decomposition exercise presented by ECLAC (2011) notes that income per adult, and specifically earnings, was the main factor in the fall in inequality. The demographic factor was found to have had a modest effect on inequality, as the dependency ratio fell fairly evenly across all income levels. On the basis of an analysis of four middle-income countries in the region (Argentina, Brazil, Mexico, and Peru), López-Calva and Lustig (2010) conclude that two main factors account for the easing inequality in the countries: a narrowing of the wage gap between high-skilled and low-skilled workers and, to a lesser extent, an increase in government transfers to the lowest income households. This leads them to assert that in the famous "race between education and technology", to use Tinbergen's (1975) phrase, the former has taken the lead. Thus, whereas the demand for skills outpaced 
Table 1 Income inequality in Latin America

\begin{tabular}{l|l|l|l|l|l|l}
\hline & \multicolumn{3}{l}{ Gini coeficient } & \multicolumn{3}{l}{ Annual changes in Gini coefficient } \\
\hline & $\begin{array}{l}\text { Circa } \\
2002\end{array}$ & $\begin{array}{l}\text { Circa } \\
2009\end{array}$ & $\begin{array}{l}\text { Circa } \\
2013\end{array}$ & $\begin{array}{l}2002-2009 \\
(\%)\end{array}$ & $\begin{array}{l}2009-2013 \\
(\%)\end{array}$ & $\begin{array}{l}2002-2013 \\
(\%)\end{array}$ \\
\hline Argentina $^{a}$ & 0.578 & 0.510 & 0.475 & -1.8 & -1.8 & -4.8 \\
\hline Bolivia & 0.614 & 0.508 & 0.472 & -2.7 & -1.8 & -6.4 \\
\hline Brazil & 0.634 & 0.576 & 0.553 & -1.4 & -1.0 & -3.4 \\
\hline Chile & 0.552 & 0.524 & 0.509 & -0.7 & -0.7 & -2.0 \\
\hline Colombia & 0.567 & 0.553 & 0.536 & -0.4 & -0.8 & -1.4 \\
\hline Costa Rica & 0.488 & 0.501 & 0.512 & 0.4 & 0.5 & 1.2 \\
\hline Ecuador & 0.539 & 0.500 & 0.477 & -1.1 & -1.2 & -3.0 \\
\hline El Salvador & 0.525 & 0.478 & 0.453 & -1.3 & -1.3 & -3.6 \\
\hline Guatemala & 0.542 & 0.585 & & 1.1 & & \\
\hline Honduras & 0.588 & 0.554 & 0.573 & -0.8 & 0.8 & -0.6 \\
\hline Mexico & 0.514 & 0.515 & 0.492 & 0.0 & -1.1 & -1.1 \\
\hline Nicaragua & 0.579 & 0.478 & & -2.7 & & \\
\hline Panama & 0.567 & 0.526 & 0.527 & -1.1 & 0.0 & -1.8 \\
\hline Paraguay & 0.563 & 0.512 & 0.522 & -1.3 & 0.5 & -1.9 \\
\hline Peru & 0.530 & 0.469 & 0.444 & -1.7 & -1.4 & -4.3 \\
\hline Dominican Rep. & 0.537 & 0.574 & 0.544 & 1.0 & -1.3 & 0.3 \\
\hline Uruguaya & 0.455 & 0.446 & 0.380 & -0.3 & -3.9 & -4.4 \\
\hline Venezuela & 0.500 & 0.416 & 0.407 & -2.6 & -0.5 & -5.0 \\
\hline AL (simple average) & 0.548 & 0.513 & 0.492 & -1.0 & -1.0 & -2.7 \\
\hline Source Econ & & & & & & \\
\hline
\end{tabular}

Source: Economic Commission for Latin America and the Caribbean (ECLAC), on the basis of special tabulations of data from household surveys in the respective countries

aUrban areas

supply in the 1990s, the opposite appears to have happened in the past few years. Azevedo et al. (2013), analysing the employed population in 15 countries of the region, also conclude that the decline in the education premium has been driven by a greater supply of skilled workers.

A different view is put forward by Gasparini et al. (2012), who estimate the relative contribution of supply and demand factors to recent trends in the education premium in 16 countries of Latin America. They show that the relative supply of skilled and semi-skilled workers has been increasing since the 1990s. In both the 1990s and the 2000s, the returns on completion of secondary education diminished, while the returns on tertiary education increased in the 1990s but declined again in the 2000s. These authors argue that the rise in the skilled labour supply is not the only factor explaining the recent decline in inequality, and that the slowdown in relative demand for skilled labour in the last decade has also played a role. This shift in relative demand for workers with tertiary education appears to be a result of the commodity price surge, which has boosted demand for unskilled labour and driven down the education wage premium. De la Torre and Pienknagura (2012) also stress the importance of labour market changes, with workers moving from manufacturing sectors to service-intensive sectors tied to natural-resource-related production. The 
case studies presented in Cornia (2014) also show that the recent drop in inequality in the region has been facilitated by the commodity price boom, especially in the countries whose exports are most commodity intensive. It is argued that this has not been the only cause, however, as inequality has also been falling in countries that are semi-industrialized or heavily dependent on remittances.

These findings are disturbing, to say the least. They suggest that a situation could be occurring in which sectoral composition, heavily influenced as it is by natural-resource-centred economies, is generating greater relative demand for lowskilled workers, narrowing the gap in returns on education. Rather than a sign of development being reconciled with equality, this would be a warning that the combination of stagnating productivity and the region's specialization pattern is sending out signals that discourage educational progression and capability development. While this evidence is not yet conclusive and the debate is still open, it is necessary to consider this possible scenario and assess the potential implications of this interpretation of the region's recent decline in inequality. This recent story reminds us about the importance of the productive structure in the determination of income inequality.

It is also relevant to consider the political dynamic behind the recent decline in inequality in the region. Democratic life has given rise to new electoral preferences and brought social demands to greater prominence. This means that, in a positive cycle of economic stability, governments respond to these demands for social inclusion with new, more redistributive policies. In most cases, these are reforms inspired by the idea of "prudent redistribution with growth" (Cornia 2010) by way of fiscal, employment, and progressive transfer policies. Indeed, the fiscal system has generally become more redistributive than it was, although its contribution in this area remains limited.

Redistributive policies and social reforms have not been the sole preserve of left-wing governments in the region; rather, the institutionalization of electoral competition in contexts of pronounced economic and social inequality seems to have led parties and governments of different ideological stripes to strive to respond to popular demands for equality and social inclusion (Roberts 2014). In some of the countries of the region, labour market institutions do seem to have played a key role, although it has been mainly neglected by most of the related literature. As the next section discusses, some important changes in labour market institutions and dynamics may have played a key role in some specific countries.

\section{Inequality and Labour Market Institutions}

As discussed in the previous section, recent explanations for declining inequality in the region have focused on factors driving supply and demand for workers at different qualification levels. Some recent research from ECLAC suggests the importance 
of considering, in addition, the role of labour institutions in the distributive improvements in some countries of the region. Narrowing wage differentials could indeed be affected, in some countries of the region, by strengthening the minimum wage and other tools, such as formalization in the labour market. The following paragraphs, based on ECLAC (2014a) and Amarante and Arim (2015), provide some insights about the role of labour market institutions in the recent decline in wage inequality in the region.

\subsection{Inequality and Minimum Wage}

The potential effects of minimum wage hikes on labour market variables are controversial (see ECLAC 2014a). Given the fact that in some countries in the region the minimum wage rose and wage inequality declined simultaneously in a context of employment growth, it is important to assess the potential link between both features. In the following paragraphs we report some results presented in ECLAC (2014a) which illustrate the effects of minimum wage increases in Argentina, Brazil, and Uruguay (three countries where recovery of the minimum wage has been substantial) and Chile (where growth has been less striking). ${ }^{1}$

In Argentina, the minimum wage had remained at the same low nominal and real value since 1993 and plummeted in 2002. A forceful minimum wage updating policy was rolled out in 2003, leading to a sharp real increase of more than $200 \%$ between 2008 and 2012. But this uptrend faltered in 2007 as accelerating inflation ate into the gains in minimum wage purchasing power (Fig. 2). ${ }^{2}$ In Brazil, recovery began earlier than in Argentina, towards the mid-1990s, but really gathered momentum in the 2000s as the minimum wage rose around $100 \%$ in real terms between 2000 and 2012. The trend was similar, albeit less marked, in Chile, which posted an increase of about $40 \%$ over the same period. And Uruguay, the last country in which income inequality began to trend downwards, was also the last to start bolstering the minimum wage. The real value of the minimum wage in Uruguay had been dropping steadily in recent decades. The slide reversed in late 2004 , with the purchasing power of the minimum wage soaring $180 \%$ between 2005 and 2012.

The ability of governments to use the minimum wage as a labour policy instrument depends on the extent to which the economy is indexed to the minimum wage. Brazil and Uruguay are two cases in which the minimum wage has been linked to social benefits. In Brazil, under the 1988 Constitution, the minimum wage is the threshold for social benefits. In Uruguay, until 2004, the minimum wage was the reference point for determining eligibility for and the value of a

\footnotetext{
${ }^{1}$ These results are based on Maurizio (2013). It should be noted that this analysis covers countries with relatively low levels of informality in the region. In countries with highly informal economies, the minimum wage can influence informal sector wages more and tend to maintain segmentation barriers.

${ }^{2}$ Real variation is calculated using a weighted index of price indices for the provinces.
} 


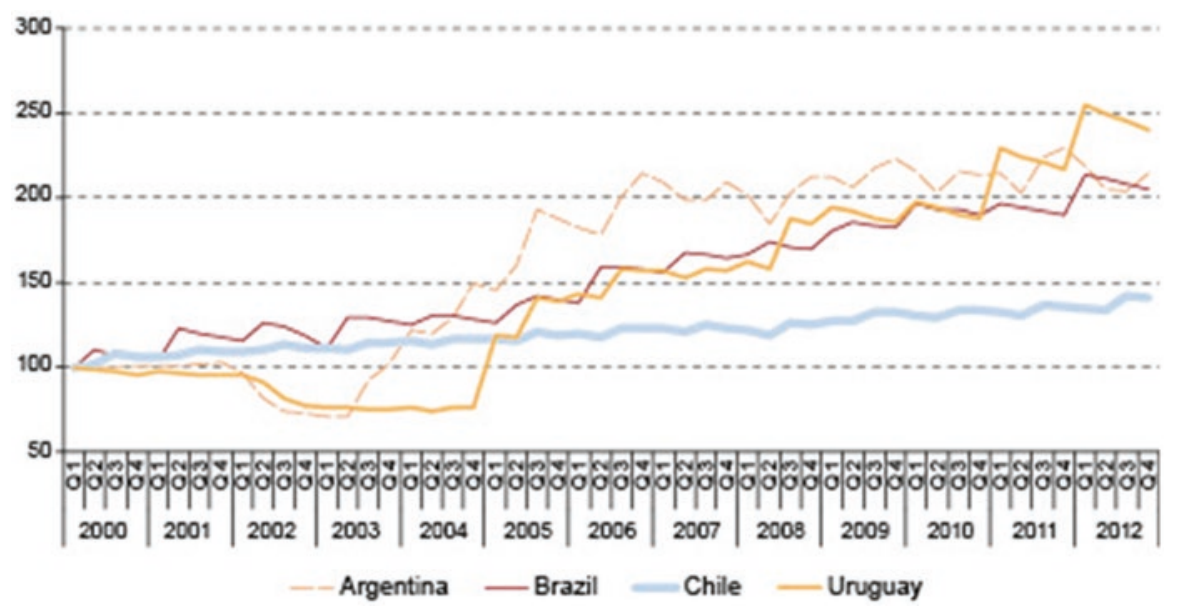

Fig. 2 Latin America (selected countries): Change in the real minimum wage, 2000-2012. (Local currencies, constant prices at latest observation.) Source: Economic Commission for Latin America and the Caribbean (ECLAC) and the International Labour Organization (ILO), on the basis of official data for the minimum wage and consumer price index (CPI) from countries

Table 2 Latin America (four countries): minimum wage in relation to the wage distribution (ratios)

\begin{tabular}{l|l|l|l|l|l}
\hline & & $\begin{array}{l}\text { Minimum } \\
\text { wage/average }\end{array}$ & $\begin{array}{l}\text { Minimum } \\
\text { wage/median }\end{array}$ & $\begin{array}{l}\text { Minimum wage/10th } \\
\text { percentile }\end{array}$ & $\begin{array}{l}\text { Minimum wage/20th } \\
\text { percentile }\end{array}$ \\
\hline \multirow{2}{*}{ Argentina } & 2003 & 0.30 & 0.39 & 0.79 & 0.61 \\
\cline { 2 - 6 } & 2012 & 0.47 & 0.53 & 1.06 & 0.81 \\
\hline \multirow{3}{*}{ Brazil } & 2003 & 0.25 & 0.44 & 0.88 & 0.65 \\
\cline { 2 - 6 } & 2011 & 0.30 & 0.50 & 0.86 & 0.72 \\
\hline \multirow{3}{*}{ Chile } & 2000 & 0.31 & 0.49 & 0.92 & 0.82 \\
\cline { 2 - 6 } & 2011 & 0.37 & 0.60 & 0.84 & 0.82 \\
\hline \multirow{2}{*}{ Uruguay } & 2004 & 0.13 & 0.18 & 0.43 & 0.31 \\
\cline { 2 - 6 } & 2012 & 0.30 & 0.37 & 0.74 & 0.59 \\
\hline
\end{tabular}

Source: ECLAC (2014a)

comprehensive package of social benefits, with the resulting fiscal impacts. The real minimum wage in Uruguay had to be de-indexed first before it could be increased. By contrast, Argentina and Chile do not use the minimum wage for setting other wage levels or social benefits, so raising it does not lead directly to higher fiscal costs.

The relationship between the minimum wages and salaries actually paid in each economy is tracked in Table 2 using the ratio between the minimum wage and various measures of distribution (average wage, the median (Kaitz index), and the lowest wage distribution percentiles). In the countries reviewed, the minimum wage represents approximately $50 \%$ of the median for the most recent year, except in Uruguay 
where the ratio is lower. In all countries, the minimum wage recovered more sharply than did other pay scale indicators, driving the ratios up. This indicates that the minimum wage has become more "operational" for all of the countries. Argentina has the highest minimum wage (equivalent to tenth-percentile wages). Uruguay has the lowest (74\% of tenth-percentile wages).

For the minimum wage to play its role properly, it must not only be appropriate in relation to the wage distribution - but it must also be complied with. In this regard, it is useful to break down employment by minimum wage brackets for the years taken for the simulation set out below. ${ }^{3}$ About $8 \%$ of wage workers in Argentina were drawing less than the legal minimum wage in 2012, and a similar portion were at or near the minimum wage. The remaining $84 \%$ were earning wages above the figure established by law. Among participants in the pension system (referred to here as formal workers), only $2 \%$ were below the minimum; this figure climbs to $27 \%$ for informal workers. The proportion of formal workers in the area of the minimum wage was very low (4\%), while $20 \%$ of informal workers were in that range. This means that in 2012, $94 \%$ of the reported workers were earning more than the statutory minimum wage. This figure was almost $100 \%$ in 2003 because the minimum wage was very low, making it completely non-binding.

In Brazil, compliance with the minimum wage seems to be higher than in the other three cases. In 2011, only $1.3 \%$ of wage workers were paid less than the minimum; $8 \%$ were at or near the minimum wage (Table 3). Therefore, $90 \%$ of the workforce had incomes above the minimum wage. The percentage of unreported workers whose wages were below the minimum is also very low $(8.3 \%)$, significantly lower than, for example, in Argentina (27\%). Moreover, in Brazil the distribution of workers (wage earners and non-wage earners) with reference to the minimum wage has not changed substantially, even during a period when the minimum was strengthened considerably. This suggests that in Brazil the minimum wage is a reference value for setting wages for informal workers. Thus, minimum wage hikes translate into effective wage increases for them, confirming prior evidence of the "lighthouse effect". ${ }^{4}$ In Chile, about $3 \%$ of the wage-earning workforce is paid less than the legal minimum wage; a similar percentage is at or near that threshold. Together with Brazil, Chile has the lowest percentage of informal workers earning less than the minimum wage. But Chile also has a small percentage of these workers (around $7.5 \%$ ) at or near the minimum wage.

Lastly, Uruguay has the highest percentage $(95 \%)$ of wage workers drawing more than the minimum wage; only $3 \%$ are below it. This reflects the fact that almost all reported workers are wage workers. However, when it comes to informal workers, Uruguay is somewhere in the middle, with about $20 \%$ drawing less than

\footnotetext{
${ }^{3}$ The following criteria were used to determine whether workers were above, at, or below the minimum wage for any given value: (1) below the minimum wage-less than $90 \%$ of the value set by law; (2) at or near the minimum wage - between 90 and $110 \%$ of the legal minimum wage; and (3) above the minimum wage - equal to or greater than $110 \%$ of the legal minimum wage.

${ }^{4}$ Neri et al. (2000) and Lemos (2004).
} 


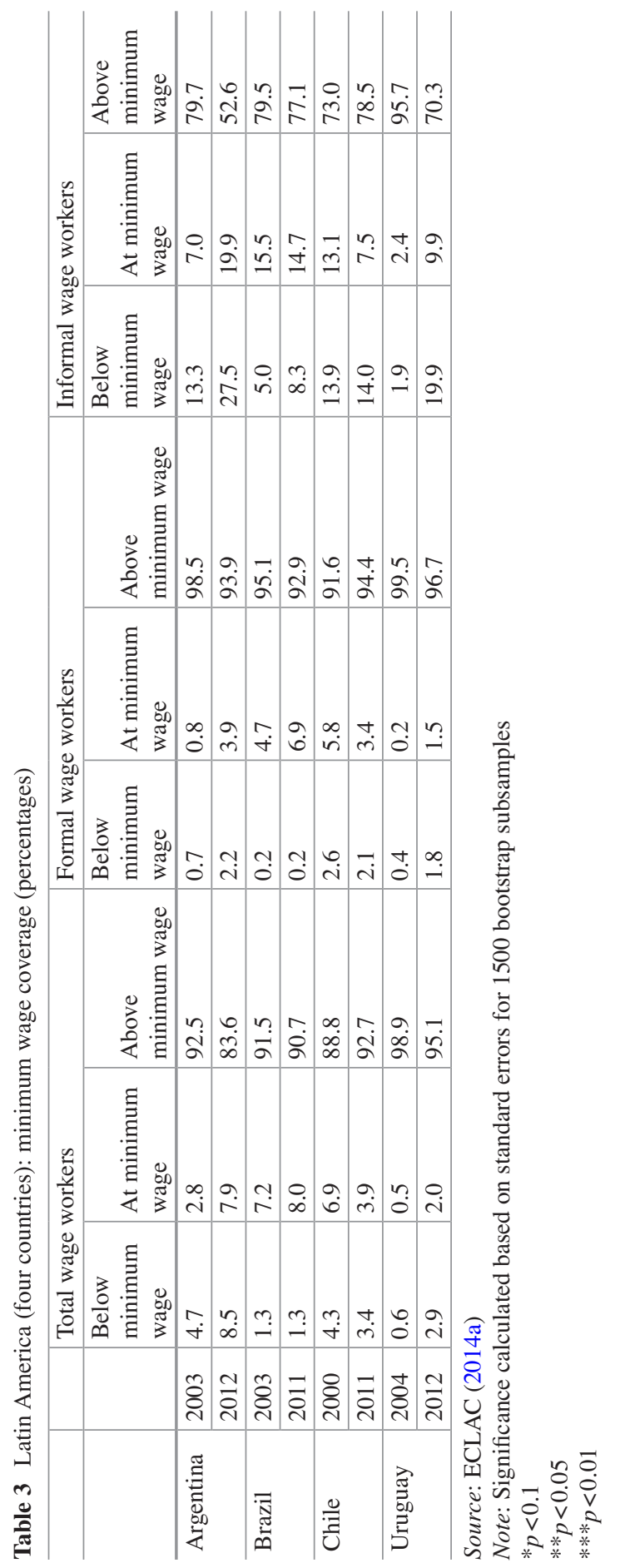


the minimum wage. This is twice the number in Chile and Brazil and 7 percentage points below Argentina.

So, the differences among the four countries with regard to the distribution of wage workers by minimum wage brackets reflect largely the situation for informal workers because the percentage of formal workers at or near the minimum wage is similar and very low in all four cases. Between 94 and $97 \%$ of formal workers earn more than the legal minimum wage.

The impact of changes in the minimum wage on wage inequality is estimated using the methodology proposed by DiNardo et al. (1996). By estimating counterfactual density functions, it assesses what the wage distribution would have been at the starting point if, keeping worker attributes constant, the minimum wage were the one in force at the endpoint. This new counterfactual distribution is then used to estimate wage inequality indicators such as the Gini coefficient, Theil index, and percentile ratios. Simulating changes in the minimum wage alone while holding other potential causes of distributional change constant makes it possible to deduce the distributive impact of an increase in the minimum wage by comparing inequality indicators at the starting point with those resulting from the simulation. ${ }^{5}$

The key findings are set out in Table 4. The first and third columns show the starting and final value of the average wage (expressed in the currency of each country, at beginning-of-period prices), the percentile ratios (percentile 90/percentile 10 , percentile 50/percentile 10, and percentile 90/percentile 50), the Gini coefficient, and the Theil index. The second column shows counterfactual density, which is the one that would have prevailed at the beginning if the minimum wage at the starting point had been the one at the endpoint. Thus, the difference between column 1 and column 2 shows the impact attributable to the change in the minimum wage (absolute and relative variation). In all cases the increase in the minimum wage drove the average wage up by between 1 and $4 \%$, depending on the country. In all of the cases there is also evidence that the minimum wage has an equalizing impact, although this impact is not significant in Chile. In Argentina, Brazil, and Uruguay, the drop in inequality is explained solely by compression at the lower end of the distribution.

In Chile, none of the slight decreases in all of these indicators (except for variance) were statistically significant. The real increase in the minimum wage in Chile was, at some $30 \%$, lower than the 100-200\% seen in the other countries reviewed. This could be one of the reasons why the rise was not enough to significantly alter the inequality indicators, which changed only marginally in absolute terms. And in Chile, unlike the other countries, the minimum wage seemed to lose

\footnotetext{
${ }^{5}$ See Maurizio (2014) for a more detailed discussion of methodological aspects. One of the limitations of this methodology is that it excludes potential negative impacts on the employment rate. However, employment grew sharply during this period in the countries under review, with a marked gain in formalization (except for Chile). A sustained rise in employment and in formal jobs would seem to suggest that increasing the minimum wage would not have had an adverse impact on employment. On the other hand, only those individuals with income below the minimum wage would be affected by any change. This lack of spillover effects points to conservative outcomes because the impacts could be larger if the intensity of the minimum wage effects decreased across the distribution.
} 


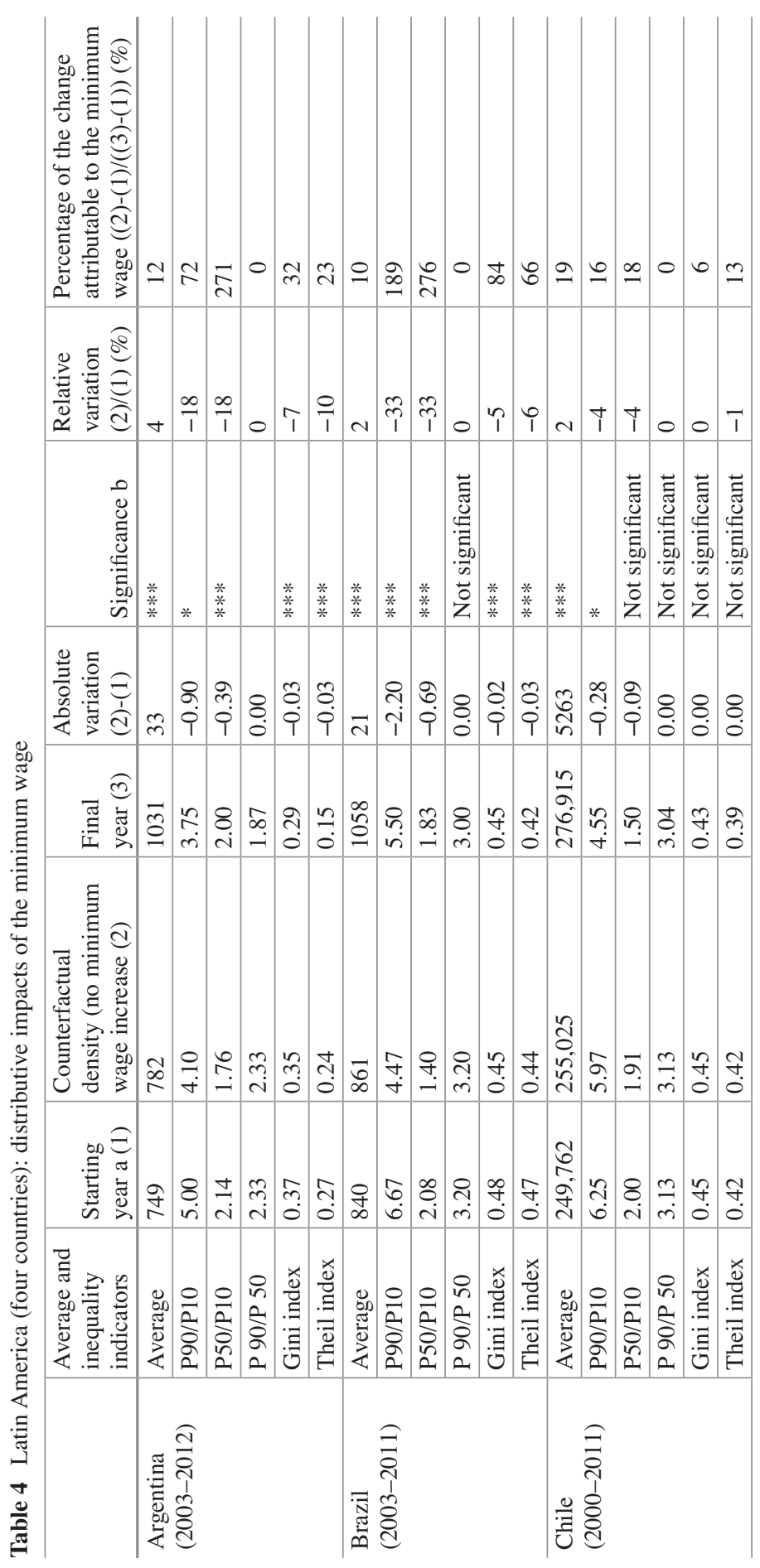




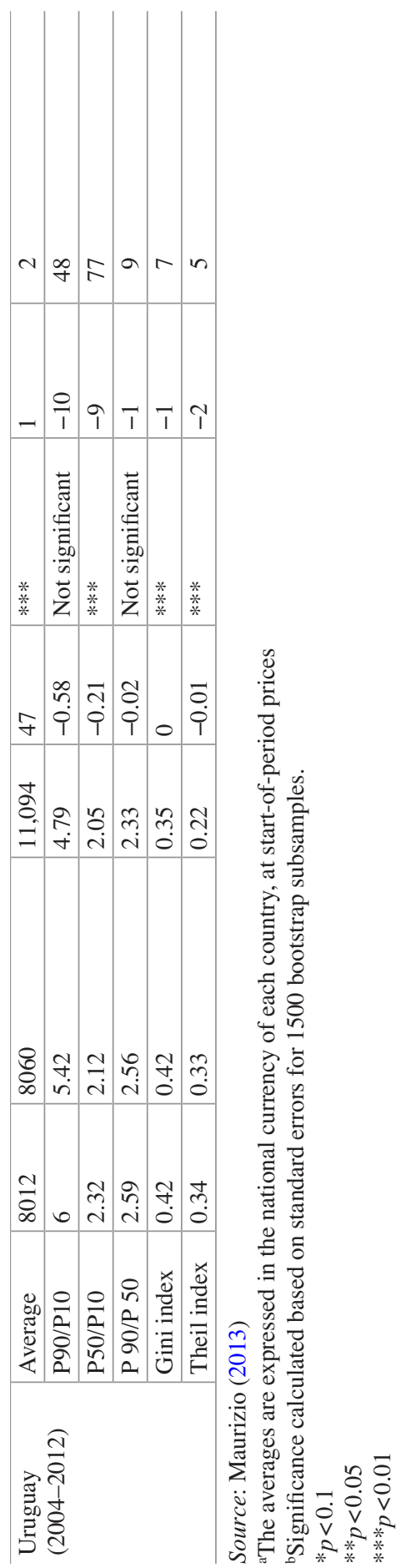


effectiveness during the second part of the subject period. As noted above, Chile is the only country where the percentage of wage workers earning one minimum wage or less is lower in year one than in the final year. Meanwhile, the minimumwage-to-first-percentile ratio declined sharply over the past few years.

In Argentina, the increase in the real minimum wage seems to be associated with a 2.6 percentage point drop in the Gini coefficient, equating to a $7 \%$ decline in this indicator compared with the initial year. About one-third of the decline in the Gini coefficient between 2003 and 2012 is attributable to changes in the minimum wage. Something similar is true of the Theil index. The ratio between the median and the 90th percentile does not change, but the percentile 50/percentile 10 gap narrows significantly, reflecting compression in the lower income brackets.

In Brazil, the Gini coefficient fell by 2.4 percentage points $(5 \%)$. The rise in the minimum wage has a very significant impact, accounting for $84 \%$ of the total drop in the Gini. As in Argentina, the equalizing impact is seen only at the bottom of the distribution. Unlike in the case of Argentina, however, the decrease is large enough to significantly narrow the gap between the outlier percentiles, 90 and 10 . The results suggest that with the minimum wage effect alone, the ratio between percentile 50 and percentile 10 of the end year would have been even lower than was actually recorded.

In Uruguay, the equalizing effects were smaller than in the two other cases. The Gini coefficient fell 0.5 percentage points; changes in the minimum wage accounted for some 7\% of the total decline in the Gini between 2004 and 2012. Outcomes for the Theil index were similar. Once again, the narrowing of the gap between the outlier percentiles of the distribution reflects only the impact at the low end, where the portion attributable to this factor was $77 \%$.

\subsection{Inequality and Formality}

A recent study for five Latin American countries (see Amarante and Arim 2015) performs a statistical decomposition of inequality measures, in order to separate what part of their changes can be attributed to changes in the distribution of observable worker characteristics (composition effect) and what part obeys to changes in returns to characteristics (price effect). Five countries are considered-Argentina, Brazil, Chile, Ecuador, and Uruguay - and the potential roles of human capital and labor informality are explored. The main finding that arises from the joint analysis of the five countries under consideration is that labour formalization, together with the combination of norms and institutional mechanisms that determine wage creation in the formal sector, contributed significantly to the decrease of inequality in the first decade of the twenty-first century in some countries of the region.

The recent body of literature investing the evolution of wage inequality over the last 15 years has identified the reduction of wage differentials conditional on education levels as the main factor explaining the recent fall. The results of the microeconometric decomposition exercises conducted in Amarante and Arim 
Table 5 Decomposition of the Gini index

\begin{tabular}{|c|c|c|c|c|c|c|}
\hline & & Argentina & Brazil & Chile & Ecuador & Uruguay \\
\hline \multirow{3}{*}{$\begin{array}{l}\text { Informality } \\
\text { (employees) }\end{array}$} & First year & $40 \%$ & $35 \%$ & $37 \%$ & $63 \%$ & $36 \%$ \\
\hline & Final year & $33 \%$ & $23 \%$ & $31 \%$ & $47 \%$ & $24 \%$ \\
\hline & Total change & $-7 \%$ & $-12 \%$ & $-6 \%$ & $-16 \%$ & $-12 \%$ \\
\hline \multirow[t]{3}{*}{ Gini (wages) } & First year & 0.414 & 0.529 & 0.413 & 0.441 & 0.410 \\
\hline & Final year & 0.353 & 0.482 & 0.394 & 0.372 & 0.351 \\
\hline & Total change & -0.061 & -0.047 & -0.019 & -0.069 & -0.059 \\
\hline \multirow{4}{*}{$\begin{array}{l}\text { Composition } \\
\text { effect }\end{array}$} & Total & 0.001 & 0.031 & 0.020 & -0.011 & -0.010 \\
\hline & Formalization (A) & -0.008 & -0.030 & -0.006 & -0.028 & -0.020 \\
\hline & Education $(\mathrm{C})$ & 0.004 & 0.055 & 0.016 & 0.013 & 0.010 \\
\hline & Others & 0.005 & 0.006 & 0.010 & 0.004 & 0.000 \\
\hline \multirow[t]{4}{*}{ Return effects } & Total & -0.062 & -0.077 & -0.024 & -0.079 & -0.062 \\
\hline & Formalization (B) & -0.020 & -0.002 & 0.011 & -0.064 & -0.030 \\
\hline & Education (D) & -0.025 & -0.049 & 0.024 & -0.007 & -0.040 \\
\hline & Others & -0.017 & -0.026 & -0.059 & -0.008 & 0.008 \\
\hline \multirow{2}{*}{$\begin{array}{l}\text { Total effect of } \\
\text { formality }\end{array}$} & $(\mathrm{A}+\mathrm{B})$ & -0.028 & -0.032 & 0.005 & -0.092 & -0.050 \\
\hline & $\%$ of Total change & $46 \%$ & $68 \%$ & $-26 \%$ & $133 \%$ & $85 \%$ \\
\hline \multirow{2}{*}{$\begin{array}{l}\text { Total effect of } \\
\text { education }\end{array}$} & $(\mathrm{C}+\mathrm{D})$ & -0.021 & 0.006 & 0.040 & 0.006 & -0.030 \\
\hline & $\%$ of Total change & $34 \%$ & $-13 \%$ & $-211 \%$ & $-9 \%$ & $51 \%$ \\
\hline
\end{tabular}

Source: Amarante and Arim (2015)

(2015) confirm the importance of this factor. However, changes in terms of formalization levels and wage differentials between formal and informal workers are factors as important in magnitude as returns to education and changes in workers' education levels - although there is high variation across the countries studied.

In the following table, results from these national studies are summarized. Tables 5 presents changes in informality (lack of contribution to the social security) and wage inequality for employees in the five countries, and then displays the Gini index decomposition highlighting the effects of formality and education. A large portion of the informality reduction observed in the five countries is explained by the impact of formality and returns to working in the formal sector. Indeed, the total impact of formality accounts for a fall of the Gini index that ranges from 2.8 percentage points in Argentina to 9 percentage points in Uruguay. In all countries except Chile, the total equalizing effect of formalization is higher than that of education. A differential pattern is observed in Chile, where changes in inequality and in the degree of formalization were of minor magnitude. In this country, even when the increase in the number of formal workers leads to greater equality, this impact is offset by the higher wage differential in favour of formal workers, and the overall effect of formalization ends up being unequalizing (increase of the Gini by 0.5).

In all five countries, the increase in labour formality - captured by the disaggregation of the composition effect (row A) - has an equalizing effect, although it varies in magnitude. The countries where the decrease in informality was the highest (Ecuador, Brazil, and Uruguay) exhibit a major impact. In all three cases, it 

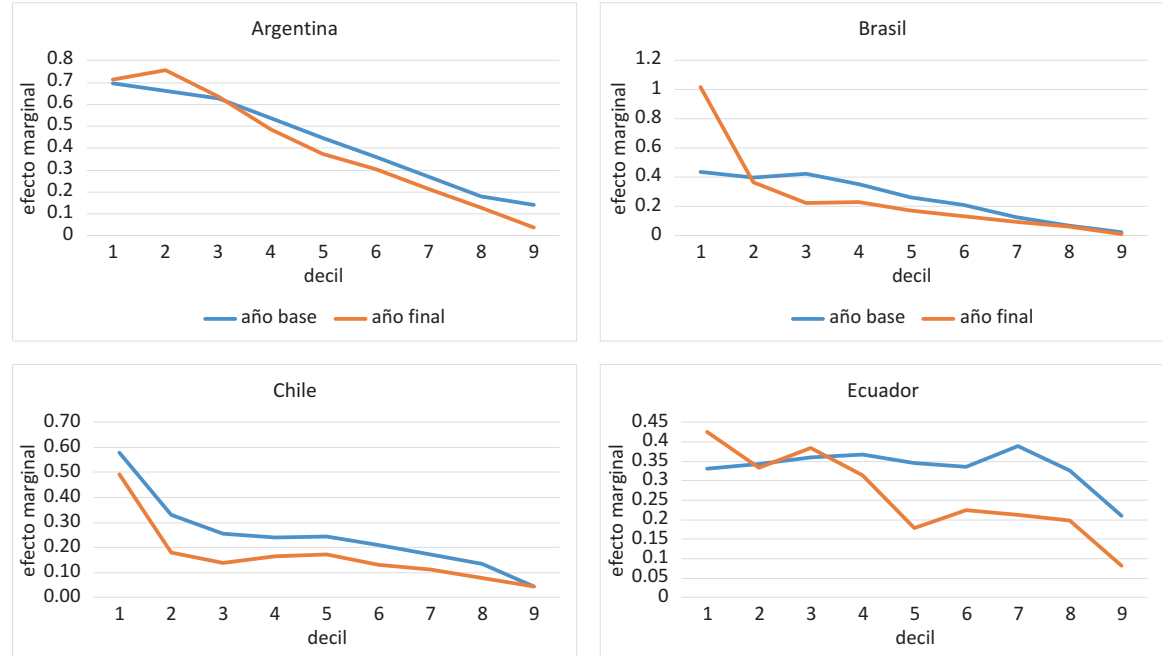

— año base —año final

— año base — año final

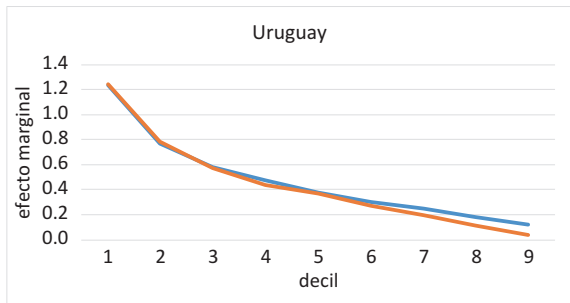

— año base —año final

Fig. 3 Marginal unconditional effect from being a formal worker, by deciles. Source: Amarante and Arim (2015)

represents three percentage points of the Gini index. In contrast, the impact of the increase in employees' education level is of the opposite sign, thus leading to high levels of dispersion in wages.

As for the decrease in the wage gap between the formal and informal sectors (row B, return effect), it favours low levels of inequality in all countries except Chile, where it has a concentrating effect. The equalizing impact of the return effect is particularly significant in Ecuador, which is directly followed by Uruguay and Argentina. The fall in wage differentials conditional on education levels leads to a decrease in inequality, again with the exception of Chile. ${ }^{6}$

Why does the reduction of informality appear to be such an important channel to reduce wage inequality? Figure 3 which displays the marginal impact of having a

${ }^{6}$ The case of Chile differs from others insofar a systematic reduction of returns to education is not observed. In particular, the gap between workers who have completed their tertiary education and workers with a primary education increases slightly. 
formal worker status for given deciles of the wage distribution, gives some hints to this question. In almost all cases, the returns to being in the formal sector appear to decrease monotonically with the decile. Given this pattern of marginal effects, a marginal increase in the degree of formalization is expected to have a greater impact in the lower parts of the distribution. In other words, these patterns are the reason why the composition effect associated with formalization results in an equalizing factor.

\section{Gender and Inequality}

Inequalities are generated in various dimensions of the market, in connection with variables such as income, participation, and access to different occupations. Not only does the labour market offer an unparalleled space for social relations, mutual recognition, and building autonomy and identity, it is also one of the arenas in which the struggle to overcome poverty and extend citizenship plays out, making it a crucial sphere for advancing towards the goal of equality. Several studies on the region's labour markets show significant changes in female labour force participation in recent decades. However, these changes have taken place at different rates in each country, and even among women in the same country, depending on their socioeconomic status, their education level, and the number of dependent minors in their households, among other factors. In the last decade, most countries have narrowed their gender gaps in labour participation and employment; yet these remain wide despite the fact that in the same period women overcame the educational disadvantages that were long considered the reason for their limited and poor labour market integration. With respect to income gaps and occupational segregation, the picture is more diverse across the countries and cannot be painted as one of progress for the region as a whole (ECLAC 2014b).

It is necessary to reduce gaps in participation, employment, and income, and to introduce policies for reconciling work and family life for men and women, as doing so will have positive effects at different levels. For one, there will be productivity gains, higher household income, and lower levels of socioeconomic inequality and household poverty. But it will also give impetus to equality in other spheres, such as the full exercise of autonomy, development of individual capacities and potential, access to contributory social protection, and broader participation in society beyond the household. All of these are central issues on the region's equality and rights agenda. A chapter in the recent Social Panorama (ECLAC 2014b) considers the gender inequalities in labour market and household income inequalities in the region. It examines the impact of women's employment on household well-being, measured in terms of their income and the distribution of that income. The following paragraphs are based on that chapter. 


\subsection{Participation, Employment, and Unemployment}

In the last decade, the overall participation rate in Latin America has held relatively steady, notwithstanding small fluctuations in different countries. The female participation rate, despite losing some momentum in relation to previous decades, continued to show moderate growth in some countries. Yet even with those increases in labour force participation, a third of working-age women still have no income of their own (ECLAC 2014a) and are classified for statistical purposes as economically inactive, regardless of their high workloads associated with their domestic responsibilities. Meanwhile, the growth in labour force participation rates for men has been less pronounced (see Fig. 4).

On the back of these developments, the gender participation gap has narrowed in most countries (ECLAC 2014b) (see Fig. 5). In 2002, the weighted average female participation rate was $63 \%$ of the rate for men, rising to $67 \%$ in 2012. Although the gap has narrowed, it nevertheless remains significant (Fig. 6). For example, the female participation rate in Guatemala, Honduras, and Nicaragua is on average half the male rate, and even in countries where the gap is smaller, the participation rate for women falls short of $80 \%$ of the rate for men (this is the case in Peru, the Plurinational State of Bolivia, and Uruguay). This means that, despite the considerable differences between the countries, there remains a broad scope for increasing women's labour market participation in all cases.

The moderate economic growth in the last decade has led to declines in the unemployment rate for both men and women. In aggregate terms for the region, the female-to-male unemployment ratio held relatively steady, although there are significant variations between countries in a context of low regional unemployment rates. However, in all countries of the region unemployment rates are significantly higher for women than for men (see ECLAC 2014b). As a result of these developments, the gender gap in employment between men and women has narrowed significantly, although broad differences still remain in all countries, as is the case for participation (see Figs. 4 and 5). On average for the region, the female employment rate stood at $65 \%$ of the male employment rate in 2012, compared with $61 \%$ in 2002. The largest gender gaps in employment were found in Guatemala, Honduras, and Nicaragua (see ECLAC 2014b).

\subsection{Labour Income of Women and Men}

A persistent feature of the region's labour markets is the systematic discrepancy between the average wages earned by men and women. In all countries of the region, women's average monthly earnings are lower than men's (see Fig. 7). The gaps vary significantly between countries: in the Plurinational State of Bolivia and Peru men earn on average over $50 \%$ more per month than women, but in El Salvador, Honduras, and Panama this difference is less than $10 \%$. This gap may in part be attributable to 


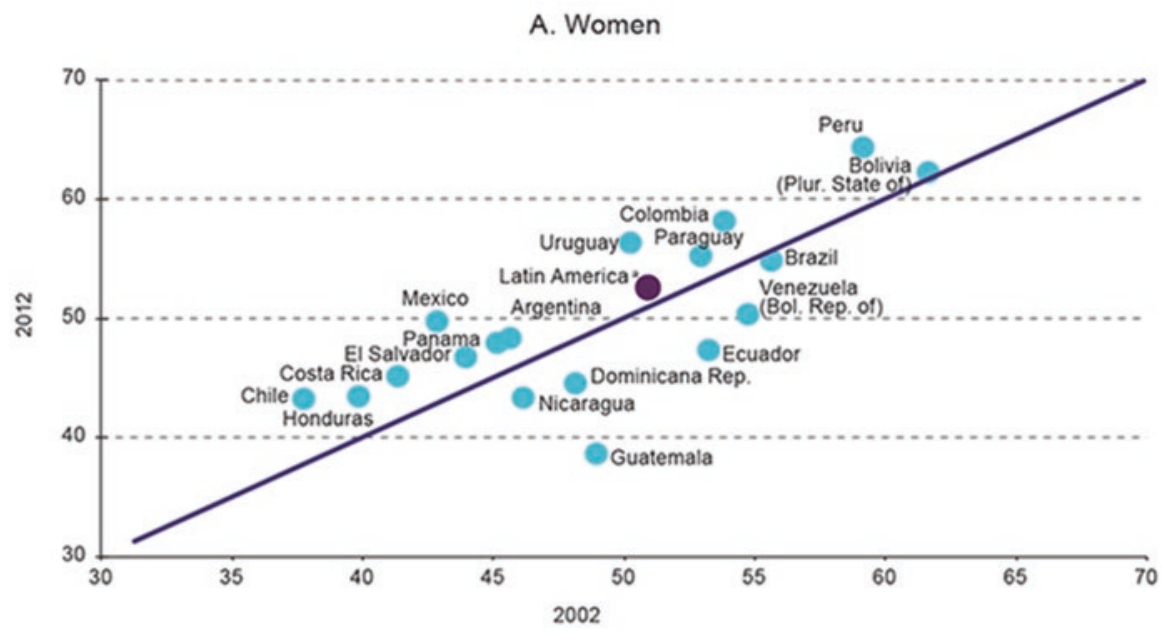

B. Men

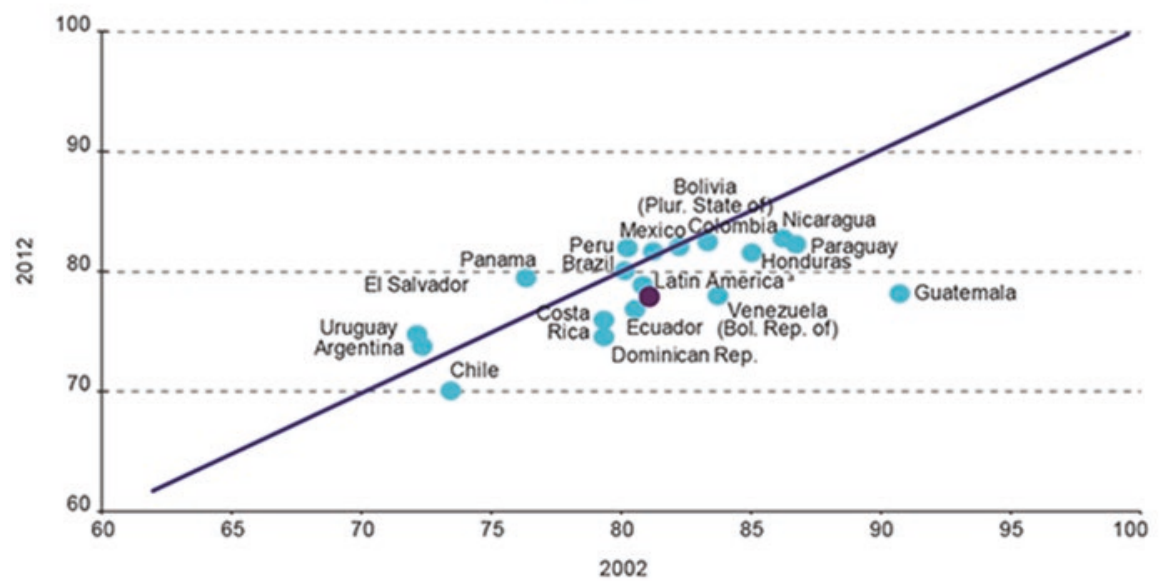

Fig. 4 Latin America (18 countries): Female and male labour force participation rates, around 2002 and 2012 (percentages). Source: Economic Commission for Latin America and the Caribbean (ECLAC), on the basis of special tabulations of data from household surveys conducted in the respective countries. ${ }^{a}$ Weighted average

the lower number of hours that women devote to paid work per month compared with men. Indeed, in 2012, men spent an average of $8 \mathrm{~h}$ per week more than women on paid work. But even when this factor is taken into account, there remains a considerable difference in average earnings by sex in most countries, although the gap does narrow somewhat. As in the case for monthly earnings, the largest gaps in hourly earnings to the detriment of women are seen in the Plurinational State of Bolivia and Peru. In some countries, such as Argentina, Costa Rica, El Salvador, Honduras, and 


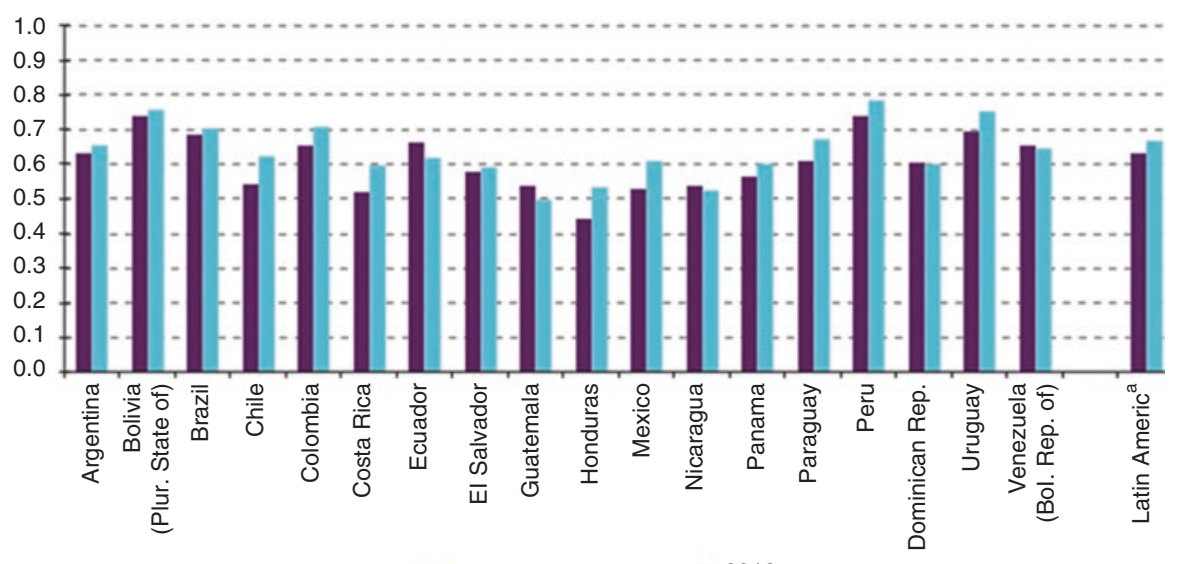

2002

2012

Fig. 5 Latin America (18 countries): Female-to-male participation ratio, around 2002 and 2012. Source: Economic Commission for Latin America and the Caribbean (b), on the basis of special tabulations of data from household surveys conducted in the respective countries. ${ }^{\text {a Weighted }}$ average

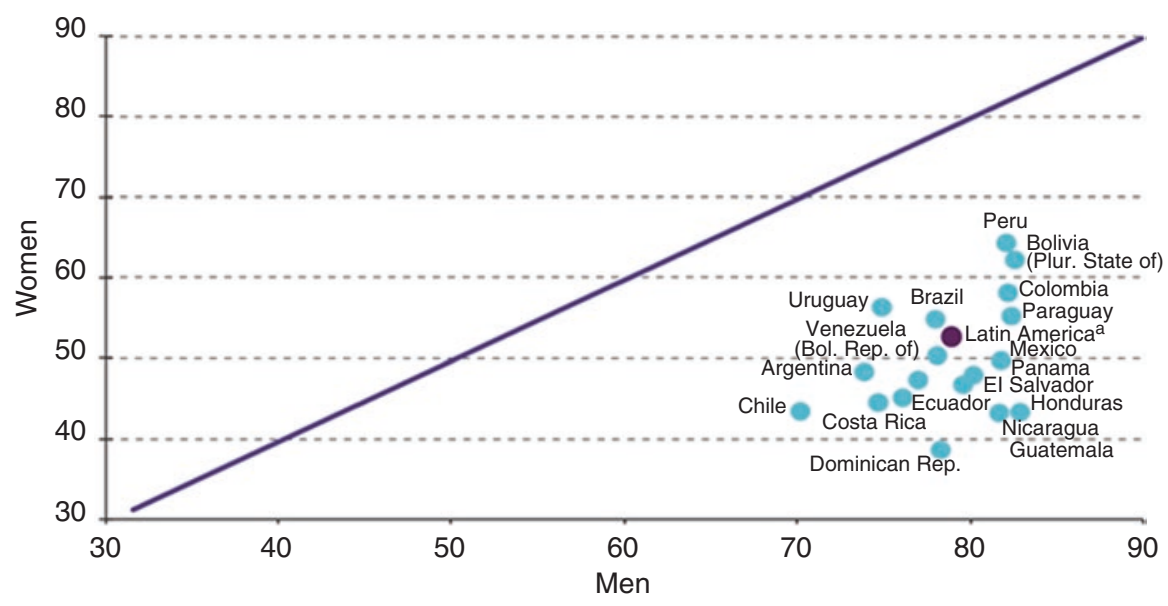

Fig. 6 Latin America (18 countries): Female and male participation rates, around 2012 (Percentages). Source: Economic Commission for Latin America and the Caribbean (ECLAC), on the basis of special tabulations of data from household surveys conducted in the respective countries. ${ }^{\text {a}}$ Weighted average

Nicaragua, wage differentials tend to disappear when controlling for hours worked. This means that in these countries, women's average hourly earnings are not lower than men's (and are even higher in some cases) (Fig. 7).

Differences in participation rates, employment, and wages between men and women combine to set a scenario in which female earnings contribute significantly 


\section{A. Monthly income}

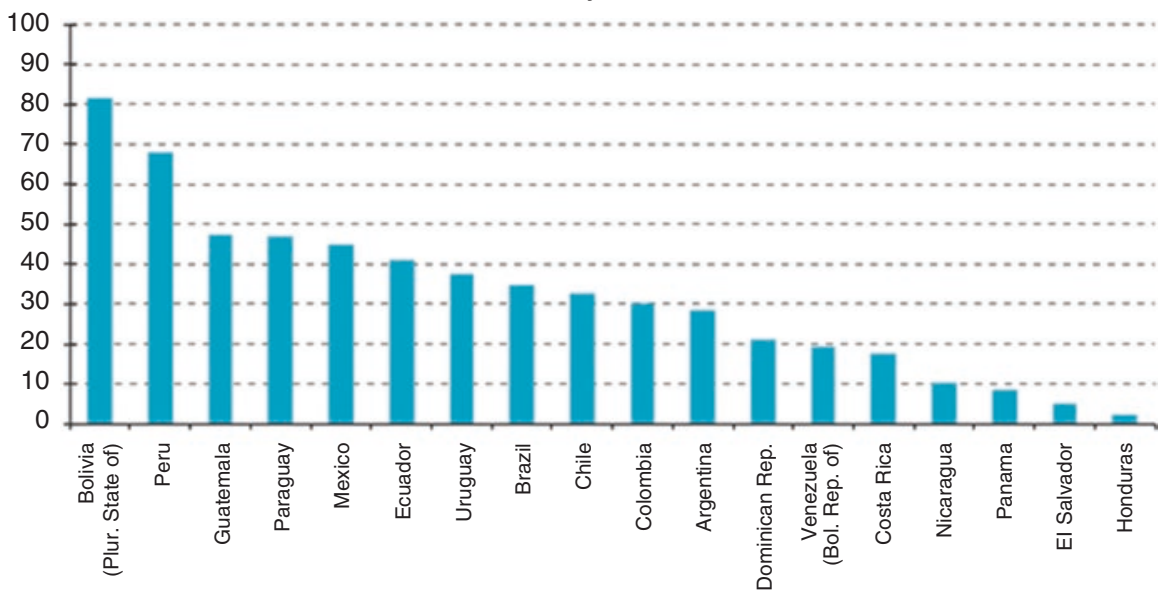

B. Hourly income

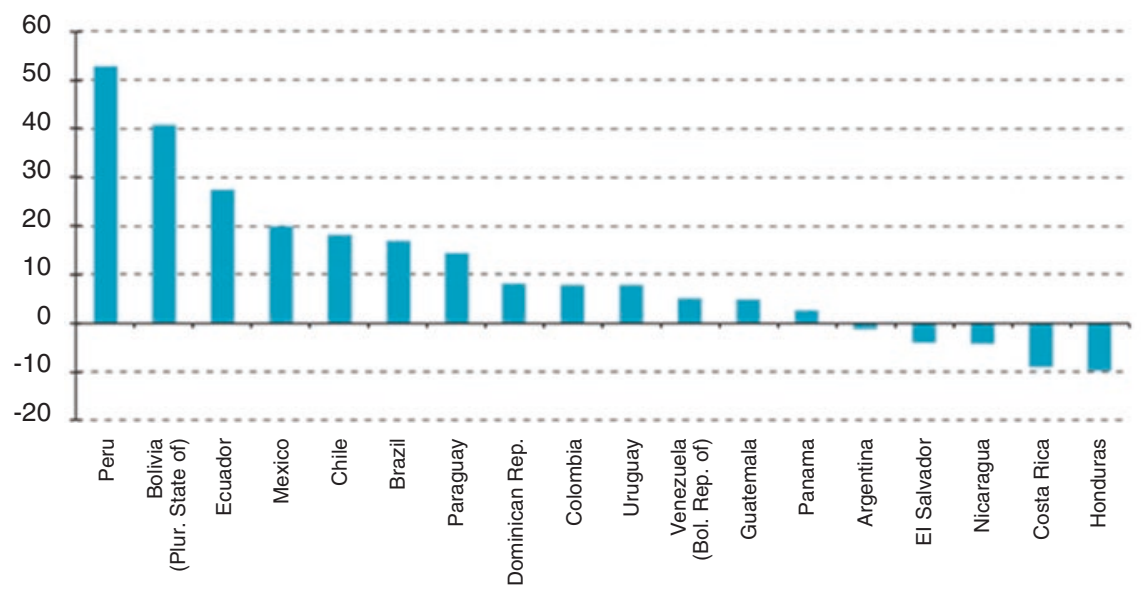

Fig. 7 Latin America (18 countries): Difference between average wages for men and women, around 2012 (percentages of female income). Source: Economic Commission for Latin America and the Caribbean (ECLAC), on the basis of special tabulations of data from household surveys conducted in the respective countries

less to household income than male earnings. Indeed, women consistently account for less than half of total household labour income. In fact, that proportion fell short of $40 \%$ in all of the countries in the region in 2012. Women make the largest proportional contribution in Uruguay, furnishing $39 \%$ on average of total household earnings, and the smallest in Dominican Republic, where their share is $26 \%$ (see Fig. 8).

Even greater heterogeneity is detected in the region regarding women's contribution to total household labour income in the lowest income quintile in each country. 


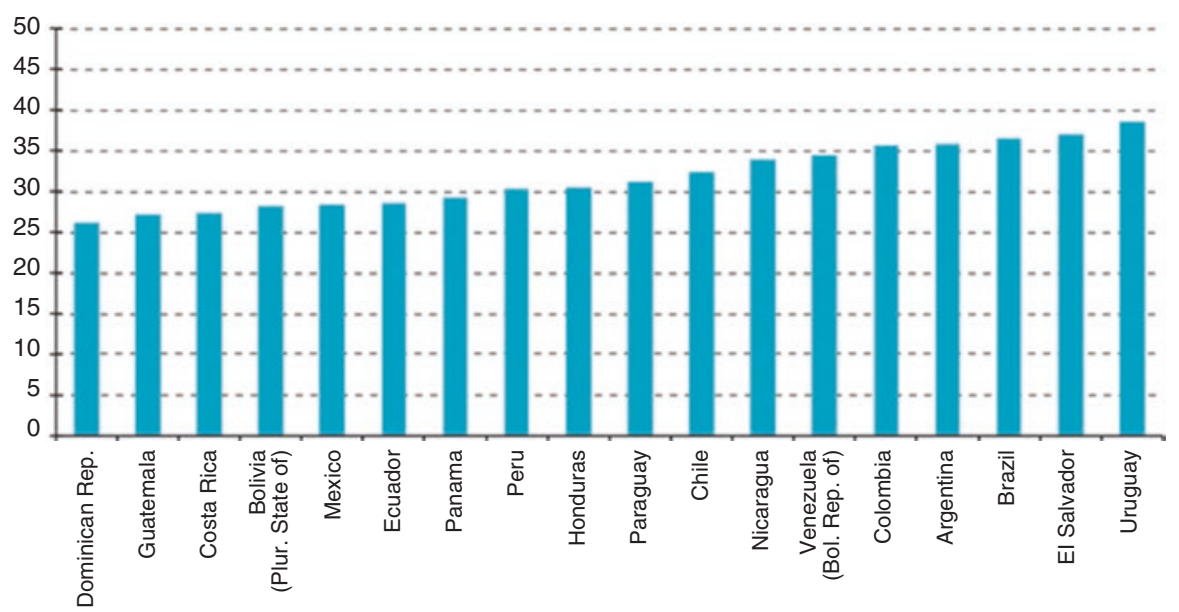

Fig. 8 Latin America (18 countries): Women's contribution to total household labour income, around 2012 (percentages). Source: Economic Commission for Latin America and the Caribbean (ECLAC), on the basis of special tabulations of data from household surveys conducted in the respective countries

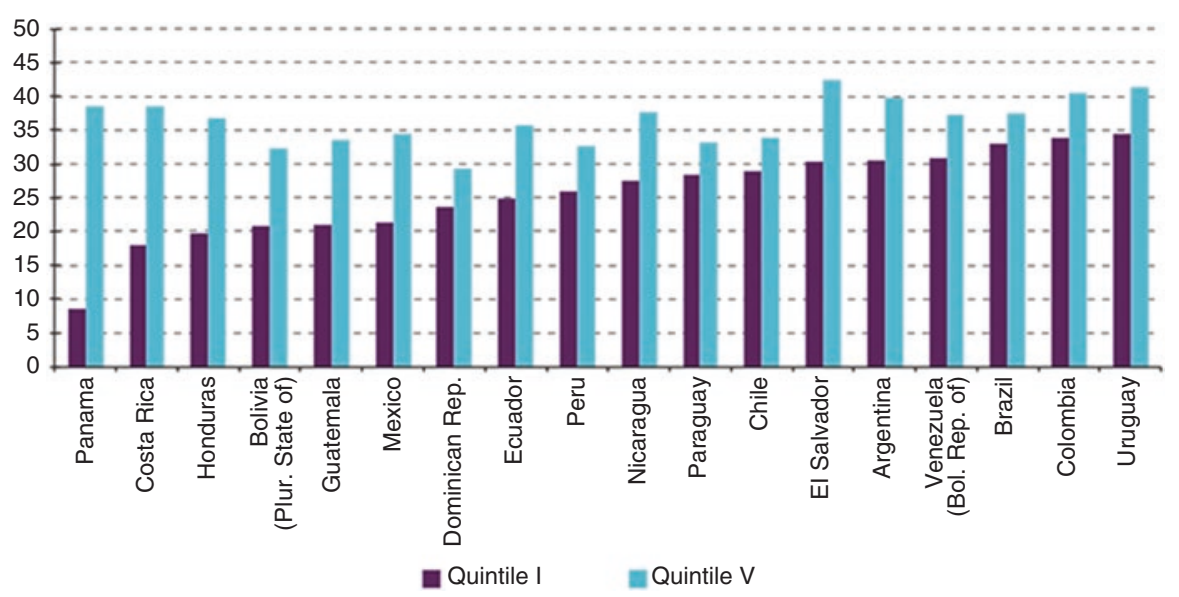

Fig. 9 Latin America (18 countries): Women's contribution to total household labour income in the first and fifth income quintiles, around 2012 (percentages). Source: Economic Commission for Latin America and the Caribbean (ECLAC), on the basis of special tabulations of data from household surveys conducted in the respective countries

Women's share of household labour income in the lowest quintiles ranges between 9 and $34 \%$, averaging $26 \%$. Meanwhile, in the highest income quintile in each country, women's contribution exceeds $29 \%$ in all cases and averages $36 \%$ (see Fig. 9). The significantly smaller share in the lowest quintile may reflect the reduced labour market participation of women in this economic stratum. 
There is therefore scope for increasing women's contribution to household income, either by expanding their labour market participation or by eliminating wage discrimination. Depending on the starting position of each country, the greatest gains can be achieved by advancing on one of these two fronts, although they are obviously not mutually exclusive. The next section examines the potential gains to be made, with the aim of promoting the formulation of public policies that are conducive to greater equality. The two scenarios taken into consideration would lead to advances in development for the countries and in the exercise of women's rights.

\subsection{Women's Labour Income and Its Effects on Inequality and Poverty}

Previously we have examined the profound differences and inequalities in the employment and earnings of men and women, showing that there is scope for improvement in terms of greater equality in these two dimensions, which will result in increased household well-being, and a more level playing field for men and women with regard to resource availability and economic capacities, and in the exercise of their social and economic rights. We now turn into quantifying the progress that could be made on some basic well-being indicators (namely the levels of socioeconomic inequality and poverty) if advances in gender equality were made in the region's labour markets.

In particular, it sets out to ascertain what the levels of income inequality and poverty would be in the region in two scenarios: (1) if the participation gap between men and women was closed, and (2) if women earned the same as men (with the same qualifications). The aim is to reflect on what the contribution of female earnings to overall household well-being could be if women's labour participation increased or the wage gap narrowed. The simulations are based on the latest information available from household surveys conducted in the respective countries, which in most cases corresponds to 2012.

Setting out to close these gaps is not a utopian exercise. The fact that these disparities are ingrained in multiple mechanisms of cultural reproduction may make them difficult to reverse, but international experience has showed that public policies on labour and care have much to contribute in these areas.

\subsubsection{Closing the Participation Gap}

The first analysis looked at what would happen if the participation rate for women in the intermediate age group (14-65 years) was similar to that for men. The first step was to develop a model of the female participation rate in order to better understand the variables determining women's participation and to be able to predict the 
probability of each woman actively entering the labour market. ${ }^{7}$ The exercise essentially consisted in simulating the incorporation of inactive women into the labour market, sorting them according to the probability predicted using the estimated model of labour force participation, and matching the female participation rates to the male rates by age group. ${ }^{8}$ That is, the women simulated as entering the labour market were those of the inactive group who were deemed most likely to become active. Once the participation gap had been closed, the probability of these newly active women being employed or unemployed was predicted, assuming a constant rate of female unemployment (that is, the percentage of unemployed women as a share of active women did not vary). ${ }^{9}$ A labour income was calculated for the women who were simulated as gaining employment, similar to the earnings of other women with the same characteristics (age and education level). A new vector of female earnings and household income was thus obtained, having knock-on effects on levels of household income, poverty, and inequality.

The simulation introduced significant changes in the participation rates for women by age group, almost closing the participation gaps between men and women (see Fig. 10).

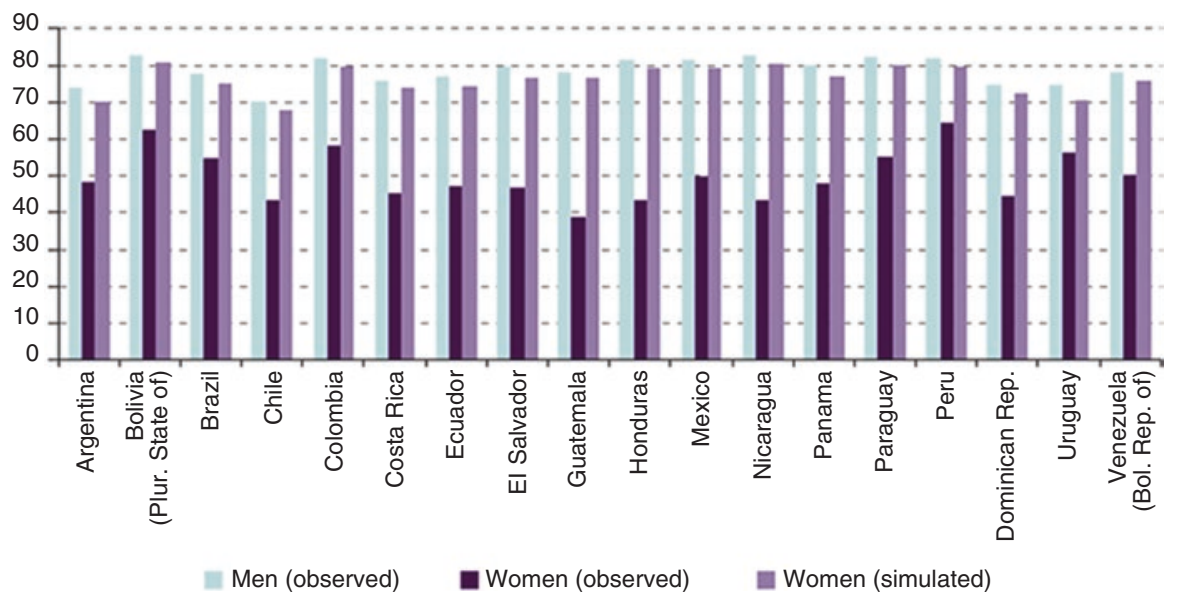

Fig. 10 Latin America (18 countries): Participation rates for men (observed) and women (observed and simulated), around 2012 (percentages). Source: Economic Commission for Latin America and the Caribbean (ECLAC), on the basis of special tabulations of data from household surveys conducted in the respective countries

\footnotetext{
${ }^{7} \mathrm{~A}$ probit model was estimated using the female participation rate as the dependent binary variable. ${ }^{8}$ The following age groups were considered: $15-24$ years, $25-49$ years, and 50-65 years. The labour force participation of women aged 65 years and older is not altered (that is, if they were originally active, they remain so).

${ }^{9} \mathrm{~A}$ second scenario was estimated matching both the participation rates and unemployment rates for men and women, thus closing the employment gap. As the results were very similar (although slightly higher) to those for the scenario of closing the participation gap, a decision was taken not to present them. The finding was attributable mainly to the low levels of unemployment recorded in the baseline year used for the simulation (2012).
} 
Such a rise in the female participation rate would lead to an increase in average household income ranging from 3 to $4 \%$ in Argentina, Brazil, Colombia, Mexico, and Uruguay, and reaching over $10 \%$ in El Salvador, Honduras, Nicaragua, and Peru. The countries with the largest gender gap in participation rates would gain the most in terms of average household income if those participation gaps disappeared. Evening up the rates of female and male participation would reduce poverty and inequality in the countries. The massive incorporation of women into the labour market could be expected to lead to declines in the poverty rate ranging from 1 percentage point in Argentina and Uruguay to over 10 percentage points in El Salvador and Nicaragua (see Fig. 11 and Table 6). In addition, if more women were to enter

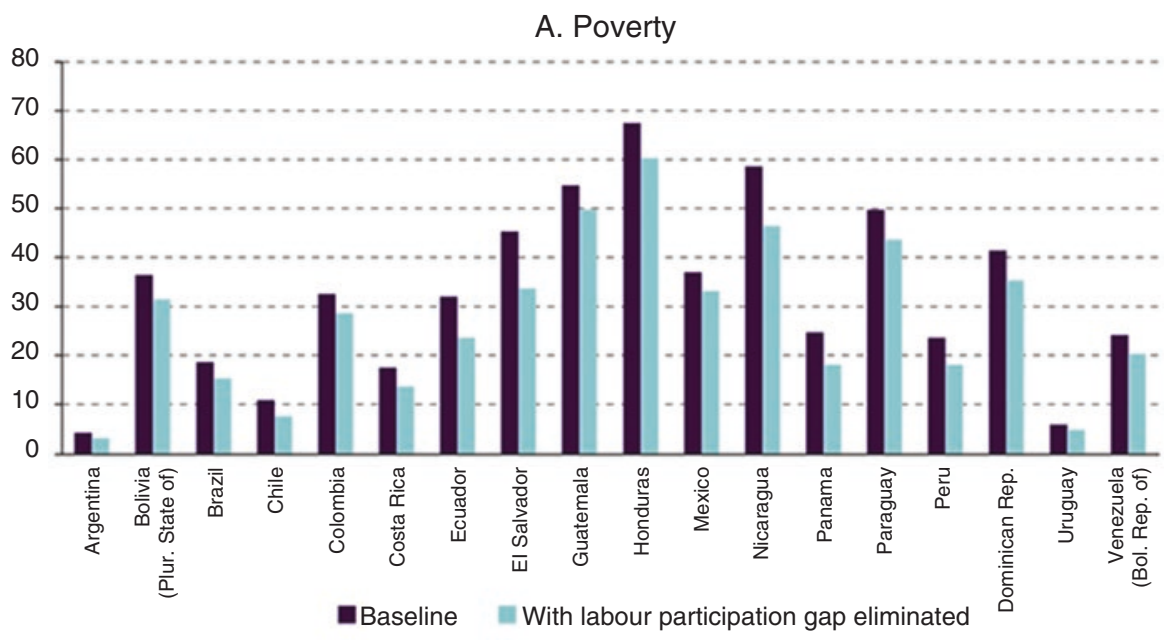

B. Gini index

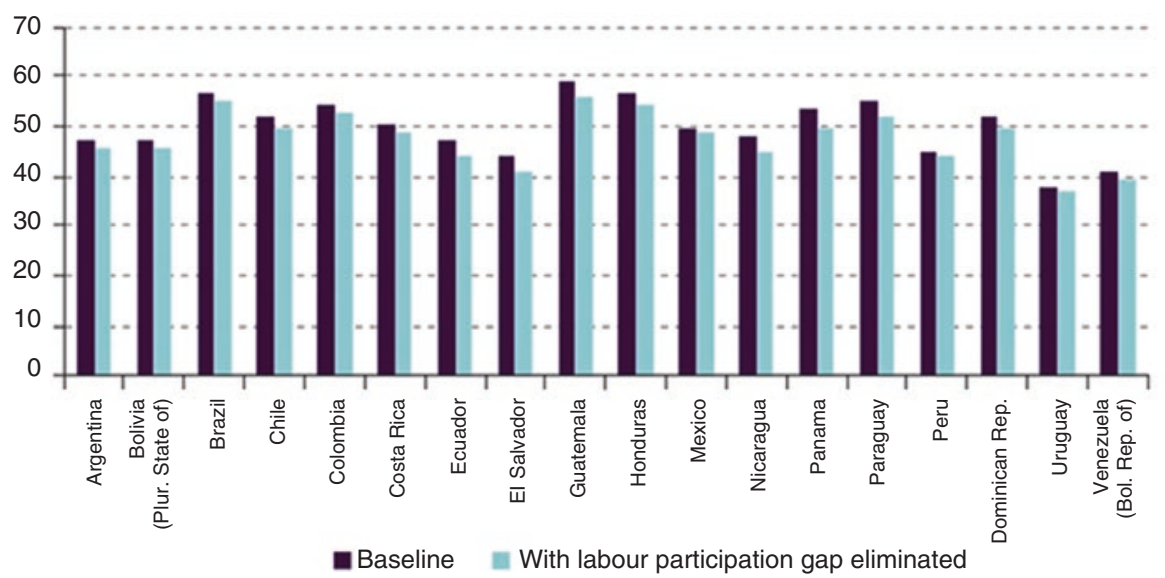

Fig. 11 Latin America (18 countries): Poverty and inequality levels as a result of closing the labour participation gap compared with a baseline scenario (percentages). Source: Economic Commission for Latin America and the Caribbean (ECLAC), on the basis of special tabulations of data from household surveys conducted in the respective countries 
Table 6 Latin America (18 countries): changes in poverty rates and inequality indicators as a result of closing the labour participation gap (percentage points)

\begin{tabular}{l|l|l|l}
\hline Country & Poverty & Gini index & Theil index \\
\hline Argentina & -1 & -2 & -4 \\
\hline Bolivia (Plurinational State of) & -5 & -1 & -3 \\
\hline Brazil & -3 & -2 & -5 \\
\hline Chile & -3 & -2 & -5 \\
\hline Colombia & -4 & -2 & -3 \\
\hline Costa Rica & -4 & -2 & -4 \\
\hline Dominican Republic & -6 & -3 & -5 \\
\hline Ecuador & -9 & -3 & -5 \\
\hline El Salvador & -12 & -3 & -5 \\
\hline Guatemala & -5 & -2 & -6 \\
\hline Honduras & -7 & -3 & -8 \\
\hline Mexico & -4 & -1 & -2 \\
\hline Nicaragua & -12 & -4 & -7 \\
\hline Panama & -7 & -4 & -8 \\
\hline Paraguay & -6 & -3 & -6 \\
\hline Peru & -6 & -1 & -1 \\
\hline Uruguay & -1 & -1 & -1 \\
\hline Venezuela (Bolivarian Republic of) & -4 & -2 & -2 \\
\hline
\end{tabular}

Source: Economic Commission for Latin America and the Caribbean (ECLAC), on the basis of special tabulations of data from household surveys conducted in the respective countries

the labour market it would help reduce inequality, measured using the Gini index, by 4 percentage points in Nicaragua and Panama, and by 3 percentage points in the Dominican Republic, Ecuador, El Salvador, Honduras, and Paraguay. The Theil index would drop sharply in some countries (6-8 percentage points in Guatemala, Honduras, Nicaragua, Panama, and Paraguay) because this measure of inequality is particularly sensitive to movements in the lower income segments and these countries would see a large increase in the proportion of women with lower levels of education entering the labour market.

The above findings show that if more women were to enter the labour market, great strides would be made in reducing poverty and inequality, with the most substantial progress being seen in the countries with the widest participation gaps, such as those in Central America. It is clear, however, that even the massive incorporation of women into the labour market would not eliminate poverty in Latin America owing to the structural characteristics of the region's labour markets. The income that these women would earn would help to improve their situation, but only to some extent. Nevertheless, some countries would register very significant progress, especially with regard to inequality. Even more importantly, the entry of women into the labour market would have a profound impact in terms of the full exercise of autonomy, the development of capacities and personal potential, access to contributory social protection, and broader participation in society. 
Accelerating changes in the proposed sense would clearly not be possible without active, resolute policies that promote and encourage such changes, including policies on care. The region has much ground to cover in this respect, because although progress has been made on a legal and regulatory front, scant substantial changes have been seen. Care services generally have low coverage and operate in a weak institutional framework, thus failing to meet the growing needs of societies. Nevertheless, several countries have incorporated the issue into their policy agendas and have made different degrees of progress (ECLAC 2012a). Active labour market policies can encourage greater participation by women in the labour market by helping to ensure that they are properly qualified and by facilitating their labour market integration. Of course, there are other policies that can influence the female participation rate, such as the provision of preschool education and extended schooldays at the primary stage. Lastly, as ECLAC has highlighted in several studies, what is needed is a new gender compact that involves a more equitable distribution of roles within the household and is thus conducive to female labour force participation.

\subsubsection{Closing the Income Gap}

The second question addressed was what would happen to poverty and inequality in the region if the income gap between men and women disappeared. In the simulations carried out for this purpose, a decision was taken to eliminate the monthly income gap between men and women, which also effaced the differences in hours worked. The first step was to estimate wage equations for employed men. The monthly earnings of women were then predicted using the coefficients of these equations. This calculation removed the gender differences in labour market returns and assumed that men and women receive equal pay in the market according to their education level and age.

Closing the gender income gap would lead to milestone achievements in poverty reduction in countries such as the Plurinational State of Bolivia and Peru (see Table 7 and Fig. 12) by significantly boosting household income. As noted above, a significant percentage of women in these countries are employed but not paid, which explains the dramatic changes that would take place if these women were to receive a similar income to men with the same level of education and work experience. The changes to the poverty level in Colombia, Ecuador, and Nicaragua would also be very significant. The Gini index would fall by between 2 and 8 percentage points, depending on the country, and the Theil index would mark an even larger decline in inequality, being more sensitive to the changes that occur in lower income households.

Again, the quest for progress on this front calls for public policy. Governments in the region have ratified international agreements and passed domestic legislation to endorse the principles of equal opportunity and non-discrimination between women and men. However, the figures indicate that these actions alone are insufficient to ensure the eradication of gender discrimination in the labour market. Once 
Table 7 Latin America (18 countries): Changes in poverty rates and inequality indicators as a result of closing the gender income gap (percentage points)

\begin{tabular}{l|l|l|l}
\hline Country & Poverty & Gini index & Theil index \\
\hline Argentina & -1 & -3 & -5 \\
\hline Bolivia (Plurinational State of) & -14 & -8 & -12 \\
\hline Brazil & -6 & -4 & -13 \\
\hline Chile & -2 & -4 & -8 \\
\hline Colombia & -9 & -5 & -12 \\
\hline Costa Rica & -4 & -3 & -7 \\
\hline Dominican Republic & -5 & -3 & -6 \\
\hline Ecuador & -8 & -4 & -8 \\
\hline El Salvador & -6 & -3 & -5 \\
\hline Guatemala & -4 & -2 & -7 \\
\hline Honduras & -1 & -2 & -6 \\
\hline Mexico & -5 & -3 & -6 \\
\hline Nicaragua & -8 & -4 & -8 \\
\hline Panama & -6 & -4 & -10 \\
\hline Paraguay & -7 & -5 & -12 \\
\hline Peru & -8 & -5 & -8 \\
\hline Uruguay & -2 & -3 & -4 \\
\hline Venezuela (Bolivarian Republic of) & -4 & -2 & -3 \\
\hline
\end{tabular}

Source: Economic Commission for Latin America and the Caribbean (ECLAC), on the basis of special tabulations of data from household surveys conducted in the respective countries

specific legislation on equal pay has been enacted, labour market institutions can play a role in helping to close gaps. Expanding the coverage of collective bargaining to include workers in traditionally excluded sectors, such as domestic workers, rural workers, and home workers, can help to narrow the gender income gap. Another approach is to address issues relating to the protection of maternal and paternal labour rights (see Maurizio 2010). Improving labour inspections can also help to eliminate discriminatory practices. Furthermore, as several studies have indicated that occupational segregation is responsible for a significant part of the gender wage gap (for example, Macpherson and Hirsch 1995), policies to address occupational segregation, for example, by training women for occupations that are not considered typically female, would narrow the wage gap. Similarly, little progress has been made to date on extending training to men for occupations that have traditionally been considered female with a view to eliminating the stereotypes and prejudices that also translate into wage discrepancies. 

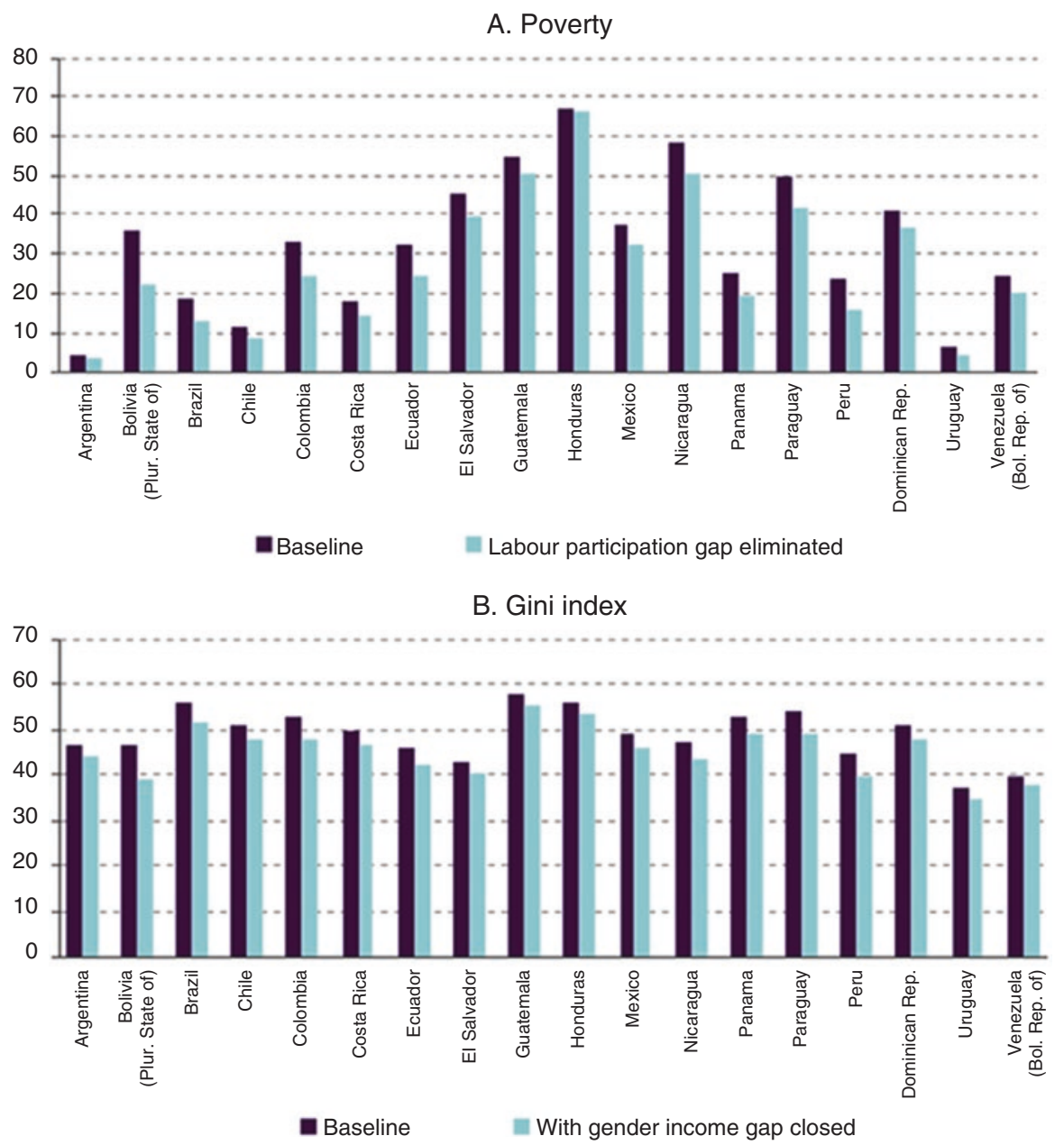

Fig. 12 Latin America (18 countries): Poverty and inequality levels as a result of eliminating the gender income gap compared with a baseline scenario (percentages). Source: Economic Commission for Latin America and the Caribbean (ECLAC), on the basis of special tabulations of data from household surveys conducted in the respective countries

\section{Final Remarks}

ECLAC has consistently promoted and reiterated the idea that the region should move towards the horizon of equality, understood in a broad sense. This chapter has summarized some recent studies from ECLAC which show that, even if very important advances were made during the last 15 years, inequality continues to be a major problem in the region. The labor market has a fundamental role to understand inequality in the region, and part of the recent inequality decline in some countries 
of the region responds to institutional factors, such as increases of the minimum wage and formalization in the labour market. Strengthening labour market institutions as well as implementing strategies for achieving gender equality are necessary actions in order to achieve higher equality.

\section{Annex (see Table A.1)}

Table A.1 Gini coefficients for the distribution of household consumption per capita. Developing countries. 2010

\begin{tabular}{l|l|l|l|l|l}
\hline & Mean & Median & Coef. var. & Min. & Max. \\
\hline East Asia and Pacific & 38.1 & 36.7 & 0.101 & 31.9 & 43.5 \\
\hline Eastern Europe and Central Asia & 33.6 & 33.7 & 0.144 & 25.6 & 43.6 \\
\hline Latin America and the Caribbean & 43.8 & 44.8 & 0.104 & 34.7 & 52.8 \\
\hline Middle East and North Africa & 36.0 & 36.1 & 0.091 & 30.8 & 40.9 \\
\hline South Asia & 35.0 & 36.3 & 0.081 & 30 & 38.1 \\
\hline Sub-Saharan Africa & 44.4 & 42.1 & 0.175 & 33.3 & 63.1 \\
\hline Developing countries & 39.8 & 39.2 & 0.181 & 25.6 & 63.1 \\
\hline
\end{tabular}

Note: Unweighted statistics

Source: Alvaredo and Gasparini (2015)

Open Access This chapter is distributed under the terms of the Creative Commons Attribution 4.0 International License (http://creativecommons.org/licenses/by/4.0/), which permits use, duplication, adaptation, distribution and reproduction in any medium or format, as long as you give appropriate credit to the original author(s) and the source, a link is provided to the Creative Commons license and indicate if changes were made.

The images or other third party material in this chapter are included in the work's Creative Commons license, unless indicated otherwise in the credit line; if such material is not included in the work's Creative Commons license and the respective action is not permitted by statutory regulation, users will need to obtain permission from the license holder to duplicate, adapt or reproduce the material.

\section{References}

Alvaredo, F., \& Gasparini, L. (2015). Recent trends in inequality and poverty in developing countries. In A. Atkinson, \& F. Bourguignon (Eds.), Chapter 10 in handbook of income distribution (Vol. 2).

Amarante, V., \& Arim, R. (2015). Desigualdad e informalidad en América Latina: Un análisis de cinco experiencias latinoamericanas. Santiago de Chile: CEPAL.

Azevedo, J. P., Dávalos, M. E., Diaz-Bonilla, C., Atuesta, B., \& Castañeda, R. A. (2013). Fifteen years of inequality in Latin America: How have labor markets helped? Policy Research Working Paper, No. 6384. Washington, DC: World Bank. 
Cornia, G. A. (2010). Income distribution under Latin America's new left regimes. Journal of Human Development and Capabilities, 11(1), 85-114.

Cornia, G. A. (Ed.). (2014). Falling inequality in Latin America. Policy changes and lessons. Oxford: Oxford University Press.

De la Torre, M., \& Pienknagura, S. (2012, October). The labour market story behind Latin America's transformation. LAC Semiannual Report. Washington, DC: World Bank.

DiNardo, J., Fortin, N., \& Lemieux, T. (1996). Labor market institutions and the distribution of wages, 1973-1992: A semiparametric approach. Econometrica, 64(5), 1001-1044.

ECLAC. (2010). Time for equality: Closing gaps, opening trails. Santiago de Chile: ECLAC.

ECLAC. (2011). Social Panorama of Latin America, 2011. Santiago, Chile: ECLAC.

ECLAC (2012). Structural change for equality: An integrated vision of development. Santiago de Chile: ECLAC.

ECLAC. (2013). Social Panorama of Latin America, 2013. Santiago, Chile: ECLAC.

ECLAC (2014a). Compacts for equality. Santiago de Chile: ECLAC.

ECLAC (2014b). Social Panorama of Latin America, 2014. Santiago de Chile: ECLAC.

Gasparini, L., Galiani, S., Cruces, G., \& Acosta, P. (2012). Educational upgrading and returns to skills in Latin America. Evidence from a supply-demand framework 1990-2010. CEDLAS Working Papers 127, Universidad de la Plata.

Lemos, S. (2004). Minimum wage policy and employment effects: Evidence from Brazil. Economia, 5(fall), 219-266.

López-Calva, L. F., \& Lustig, N. (2010). Declining inequality in Latin America: A decade of progress? Washington, DC: Brookings Institution Press.

Macpherson, D. A., \& Hirsch, B. T. (1995). Wages and gender composition: Why do women's jobs pay less? Journal of Labor Economics, 13(3), 426-471.

Maurizio, R. (2010). Enfoque de género en las instituciones laborales y las políticas de mercado de trabajo en América Latina. Serie Macroeconomía y Desarrollo, Nro. 104. Santiago de Chile: CEPAL.

Maurizio, R. (2013). El impacto distributivo del salario mínimo en la Argentina, el Brasil, Chile y el Uruguay. Serie Políticas Sociales, Nro. 194. Santiago de Chile: CEPAL.

Neri, M., Gonzaga, G., \& Camargo, J. (2000). Efeitos informais do salario mínimo e pobreza. Texto Para Discussao No. 724. Rio de Janeiro: IPEA.

Roberts, K. M. (2014). The politics of inequality and redistribution in Latin America's postadjustment era. In G. A. Cornia (Ed.), Falling inequality in Latin America. Policy changes and lessons. Oxford: Oxford University Press.

Verónica Amarante is a researcher in the area of poverty, inequality, labor market, and public policy. She worked as Social Affairs Officer at the Social Development Division in the United Nations Economic Commission for Latin America and the Caribbean. Since 2014, she has been Director of the ECLAC Office in Montevideo. Previously, she was a researcher at the Institute of Economy of Universidad de la República, Uruguay, and she still teaches at that institution. She holds a Ph.D. in Economics from the University of Sussex and an M.Sc. in Economics from Universitat Pompeu Fabra.

Antonio Prado is Deputy Executive Secretary of the United Nations Economic Commission for Latin America and the Caribbean. Prior to this, he served as Head of Governmental Affairs of the Presidency of the National Bank for Economic and Social Development (BNDES) of Brazil. During most of his professional career, Prado has specialized in the analysis of technological changes in industry and their impact on economic development, the labor market, and Brazil's industrial relations. He holds a Ph.D. in Economic Development Policies and a Master's in Industrial Economics from the State University of Campinas. 